\title{
Selective disruption of genes expressed in totipotent embryonal stem cells
}

\author{
Harald von Melchner, ${ }^{1-3}$ James V. DeGregori, ${ }^{3}$ Helen Rayburn, Sita Reddy, Christina Friedel, ${ }^{1}$ and \\ H. Earl Ruley ${ }^{2,4}$ \\ Center for Cancer Research and Department of Biology, Massachusetts Institute of Technology, Cambridge, Massachusetts \\ 02139 USA
}

Two retrovirus promoter trap vectors (U3His and U3Neo) have been used to disrupt genes expressed in totipotent murine embryonal stem (ES) cells. Selection in L-histidinol or G418 produced clones in which the coding sequences for histidinol-dehydrogenase or neomycin-phosphotransferase were fused to sequences in or near the $5^{\prime}$ exons of expressed genes, including one in the developmentally regulated $R E X-1$ gene. Five of seven histidinol-resistant clones and three of three G418-resistant clones generated germ-line chimeras. A total of four disrupted genes have been passed to the germ line, of which two resulted in embryonic lethalities when bred to homozygosity. The ability to screen large numbers of recombinant ES cell clones for significant mutations, both in vitro and in vivo, circumvents genetic limitations imposed by the size and long generation time of mice and will facilitate a functional analysis of the mouse genome.

[Key Words: Promoter trap; retrovirus; embryonal stem cells; insertional mutagenesis]

Received October 23, 1991; revised version accepted March 10, 1992.

The long reproduction cycles and large genomes of mammals generally preclude the types of genetic analysis possible with simpler organisms. Although genes responsible for organismal phenotypes can be isolated, the process is slow, requires relatively detailed physical maps, and is limited to a small number of mutant alleles (Reith and Bernstein 19911.

Alternative approaches may circumvent some of these limitations. Particularly promising has been the use of embryonal stem (ES) cell lines to construct strains of mice in which genes have been mutationally disrupted. ES cells, derived from the inner cell mass of mouse blastocysts, can be cultured for extended periods while maintaining a totipotent differentiation potential (Evans and Kaufman 1981; Martin 1981; Doetschman et al. 1985). Early embryos injected with ES cells are able to develop as chimeras and transmit genes from the ES cells to their transgenic offspring.

Although it is possible to target genes by homologous recombination (for review, see Capecchi 1989; Kessel and Gruss 1990), it is also desirable to isolate previously unknown genes responsible for recessive phenotypes, because genes required for biological function generally cannot be predicted in advance. One approach has used exogenous DNA or retroviruses as insertional mutagens

\footnotetext{
${ }^{2}$ Corresponding authors.

${ }^{3}$ These authors have contributed equally to this study.

Present addresses: ${ }^{1}$ Department of Hematology, University of Frankfurt Medical School, 6000 Frankfurt/Main, Germany; ${ }^{4}$ Department of Microbiology and Immunology, Vanderbilt University School of Medicine, Nashville, Tennessee 37232-2363 USA.
}

(Schnieke et al. 1983; King et al. 1985; Stewart et al. 1985; Sanes et al. 1986; Soriano et al. 1987; Kratochwil et al. 1989; Spence et al. 1989; Weiher et al. 1990), in which genes associated with recessive phenotypes can be cloned from sequences near the sites of integration. Unfortunately, the probability that a recessive phenotype will result from DNA or provirus integration is low, $10 \%$ and 5\%, respectively (Gridley et al. 1987; Jaenisch 1988).

To increase the efficiency of insertional mutagenesis, several types of vectors have been developed that select for integrations in expressed genes. One strategy involves inserting a selectable marker gene downstream of a splice acceptor site. Integration of the vector, delivered either by DNA transfer or retrovirus infection, into introns of expressed genes allows expression of the marker gene (Brenner et al. 1989; Gossler et al. 1989; Friedrich and Soriano 1991). A second strategy involves inserting a selectable marker gene into U3 (von Melchner and Ruley 1989; von Melchner et al. 1990; Reddy et al. 1991). When the viruses are passaged, the elongated U3 regions form part of the long terminal repeats (LTRs) that flank the integrated provirus. As a result, coding sequences in the 5' LTR are placed only 30 nucleotides from the flanking cellular DNA. Selection for U3 gene expression invariably generates cell clones in which the gene in the $5^{\prime}$ LTR is expressed on transcripts initiating in the flanking cellular DNA. Cellular promoters that activate U3 gene expression are typically expressed prior to integration; thus, the viruses function as promoter traps (von Melchner et al. 1990).

In this study we demonstrate that the U3His and 
U3Neo promoter trap vectors can be used to selectively disrupt genes expressed in totipotent ES cells. Of 10 ES cell lines tested that expressed cell-virus fusion genes, 8 generated germ-line chimeras, including one involving the disruption of a known developmentally regulated gene. The results demonstrate that in principle, large numbers of recombinant clones recovered after promoter trap selection can be screened both in vitro and in vivo for genetically significant mutations, thus facilitating a functional analysis of the mouse genome.

\section{Results}

\section{Construction of the U3Neo promoter trap vector}

The U3Neo vector was derived from pGgTKNeoU3Hisen(-1)(von Melchner and Ruley 1989) by replacing the HisD gene with the neomycin-phosphotransferase (neo)-coding sequence derived from $\mathrm{Tn} 5$ and deleting the TkNeo from the body of the virus (Fig. 2, below). Cell lines producing ecotropic U3Neo viruses were generated by transfecting $20 \mu \mathrm{g}$ of pGgU3Neo(en - ) into $\Psi 2$ helper cells. Viruses produced from cloned producer lines were titered on NIH-3T3 cells by selecting in G418. Because the U3Neo vector lacked a constitutively expressed drug resistance marker, titers were derived by multiplying the number of neomycin resistance $\left(\mathrm{Neo}^{\mathrm{r}}\right)$ colonies with the average frequency of integrations that enable U3 gene activation of other promoter trap vectors (von Melchner and Ruley 1989; von Melchner et al. 1990; Reddy et al. 1991).

\section{Selection for U3His and U3Neo gene fusions in cultured ES cells}

ES cells are susceptible to retrovirus infection and can be used to introduce integrated proviruses to transgenic offspring (Evans et al. 1985; van der Putten et al. 1985; Robertson et al. 1986; Stewart et al. 1985). However, the proviral LTRs are transcriptionally inactive; therefore, drug resistance genes expressed from the LTR are transduced into ES cells $10^{4}-10^{6}$ times less efficiently than into murine fibroblasts. Moreover, the polyadenylation signal in the LTR and binding sites for trans-acting repressors interfere with the activation of proviral genes by transcriptional elements in the flanking cellular DNA (Sorge et al. 1984; van der Putten et al. 1985; Barklis et al. 1986; Feuer et al. 1989; Tsukiyama et al. 1989; Loh et al. 1990; Akgün et al. 1991). Consequently, the proviruses in rare resistant clones contain deletions or have integrated in regions near strong transcriptional promoters where LTR sequences are removed by RNA splicing (Barklis et al. 1986; Peckham et al. 1989).

Nevertheless, we assumed that the U3His and U3Neo vectors would usurp cellular promoters in ES cells as efficiently as in NIH-3T3 cells, because integration fuses the histidinol-dehydrogenase (his) or neo genes directly to the cellular DNA, outside of the viral sequences that otherwise interfere with activation /von Melchner et al. 1990|. This assumption proved correct with the U3His virus, as similar numbers of histidinol-resistant $\left(\mathrm{His}^{\mathrm{r}}\right)$ 140/10 ${ }^{6}$ ES-D3 and 122/NIH-3T3 cells, respectively) colonies arose in both cell types, following infection with $10^{6} \mathrm{Neo}^{x}$ transducing viruses. However, although similar numbers of $\mathrm{Neo}^{\mathrm{r}}$ colonies were obtained after infecting ES-D3 cells with U3Neo viruses, transduction of $\mathrm{Neo}^{\mathrm{r}}$ to NIH-3T3 cells was 100 -fold more efficient. This is because transcripts initiating in the 5' LTR and extending through the $3^{\prime}$ neo gene are expressed in 3T3, but not in ES, cells (see below).

The response of ES cells to selection in $3.5 \mathrm{~mm}$ L-histidinol was complex (Fig. 1). Many cells appeared to differentiate, forming an adherent fibroblast-like monolayer. In cultures infected with the U3His virus, two types of $\mathrm{His}^{\mathrm{r}}$ colonies developed after 14 days of selection. The first type resembled adherent embryoid bodies containing peripheral endodermal cells separated from a central core of undifferentiated cells (Robertson 1987). In some cases, cells in the interior of the colony died, leaving a ring of differentiated cells. The second type 110 $15 \%$ of all colonies) resembled rapidly proliferating undifferentiated stem cells. Only colonies of this type were expanded for further analysis. In contrast, G418 selection was more efficient. Thus, after 6 days in G418, only rapidly proliferating undifferentiated colonies survived.

Southern hybridization analysis of $\mathrm{His}^{\mathrm{r}}$ and $\mathrm{NeO}^{\mathrm{r}}$ clones indicated that in all cases his or neo sequences had duplicated as part of the LTR (data not shown). Most His $^{r}$ clones contained one or two proviruses, consistent with the estimated multiplicity of infection (m.o.i.) (data not shown). However, each $\mathrm{Neo}^{\mathrm{r}}$ line contained one provirus per cell indicating that the actual m.o.i. was $<1$. Rearrangements of proviral sequences were observed in 5 of $15 \mathrm{His}^{\mathrm{r}}$ and 1 of $10 \mathrm{Neo}^{\mathrm{r}}$ lines. In the two His ${ }^{\mathrm{r}}$ clones examined further, the body of the provirus was deleted as a result of homologous recombination between the elongated LTRs. This is a higher rate of deletion than has been observed for U3His in NIH-3T3 cells and may reflect selection against a transcriptional silencer located in the tRNA primer-binding site (Feuer et al. 1989; Loh et al. 1990; Petersen et al. 1991).

To determine whether transcripts in $\mathrm{His}^{\mathrm{r}}$ and $\mathrm{Neo}^{\mathrm{r}}$ clones initiate within the flanking cellular DNA, total RNA was analyzed by an RNase protection assay (von Melchner and Ruley 1989). As shown in Figure 2, all clones expressed transcripts through the left $\left(5^{\prime}\right)$ LTR, indicating that U3 gene expression was activated by flanking cellular promoters. Unlike NIH-3T3 cells, transcripts extended only occasionally through the right $\left(3^{\prime}\right)$ LTR (e.g., clone 1B6; Fig. 2) because the LTR and thymidine kinase $(\mathrm{tk})$ promoter are transcriptionally inactive in ES cells (Pellicer et al. 1980; Jahner et al. 1982; Stewart et al. 1982; Gautsch and Wilson 1983; Niwa et al. 1983; Stewart et al. 1985).

\section{Sequences adjacent to U3His and U3Neo proviruses hybridize to single-copy DNA and contain transcribed exons}

DNA was extracted from $\mathrm{His}^{\mathrm{r}}$ and $\mathrm{Neo}^{\mathrm{r}}$ cell lines that 


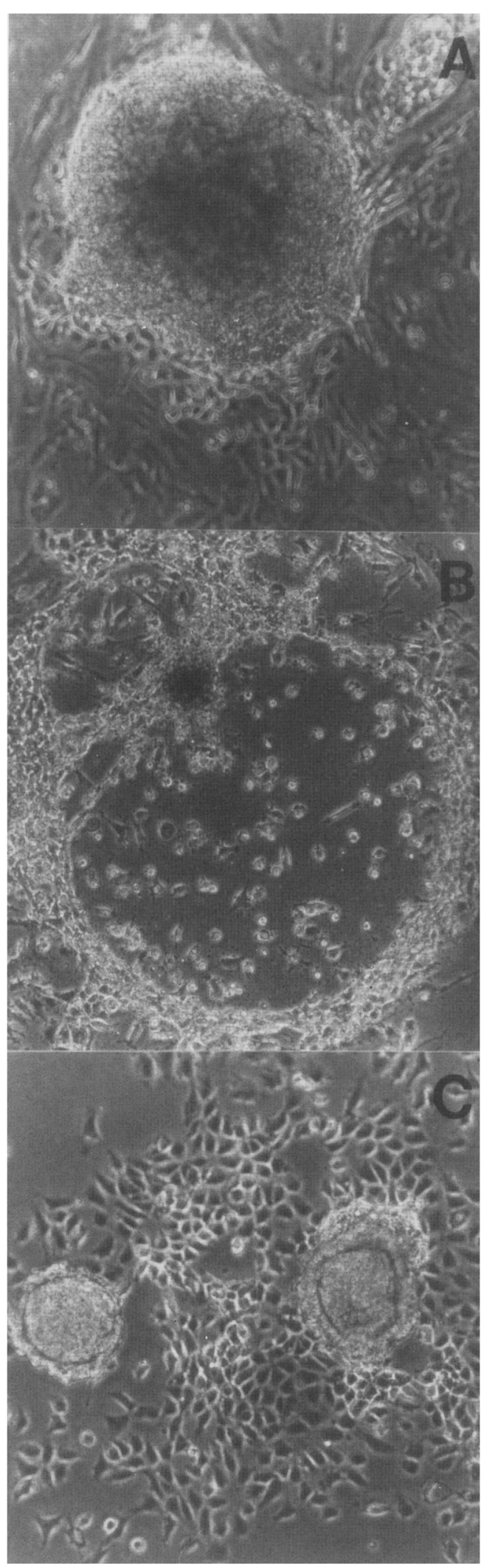

Figure 1. ES cell cultures after 14 days in $3.5 \mathrm{~mm} \mathrm{~L}$-histidinol at $100 \times$ magnification. $(A)$ Undifferentiated colony; $|B|$ differentiated cells surrounding the area of detached cells; $(C)$ simple embryoid bodies. contained a single provirus (Table 1). Sequences upstream of the proviruses were amplified by inverse polymerase chain seaction (PCR) (von Melchner et al. 1990) and cloned. Each of the flanking sequences hybridized to a single restriction fragment present in ES cell DNA and thus were derived from single-copy cellular DNA (Table 1). As expected, an additional hybridizing fragment was observed in DNA from the appropriate $\mathrm{His}^{\mathrm{r}}$ or $\mathrm{Neo}^{\mathrm{T}}$ line, corresponding to the allele occupied by the provirus (data not shown).

Five flanking sequence probes $\mid 4 \mathrm{~A} 1,4 \mathrm{~A} 3,4 \mathrm{~A} 7,1 \mathrm{~A} 4$, and $1 \mathrm{~B} 4$ ) hybridized to cellular transcripts in uninfected cells (Table 1; Fig. 3). This indicates that promoters were active prior to integration and were not activated as a result of integration. In the appropriate provirus-containing cells, each probe detected an additional RNA species that also hybridized to his (4Al, 4A3, and 4A7) or neo (1A4 and 1B4), as expected of fusion transcripts expressed by the allele occupied by the provirus (Fig. 3B).

his and neo transcripts in each clone varied in size, reflecting differences in the amount of appended cellular RNA (Fig. 3B). Cell-derived sequences were short, presumably because efficient translation would select for integrations in which the U3 gene provides the first initiation codon in the fusion transcript and the untranslated leader of the average mammalian transcript is only $\sim 75$ nucleotides (Kozak 1980; Mulligan and Berg 1981; Peabody et al. 1986; Kaufman et al. 1987; Kozak 1987b). For this reason some upstream sequences may have been too short to detect corresponding transcripts (Table 1). For example, PCR products cloned from the 1A4 cell line contained only 38 nucleotides of flanking sequence and initially did not detect cellular sequences in either Southern or Northern blots. However, satisfactory probes were prepared (Fig. 3, and data not shown) after labeling a flanking sequence oligonucleotide with terminal transferase (Johnson 1991).

\section{Disruption of the developmentally regulated REX-1 gene}

Computer analysis of upstream flanking sequences revealed that a 59-nucleotide region flanking one provirus (4A1) was identical to $5^{\prime}$-noncoding sequences within the cDNA of a previously characterized gene, REX-1 (Fig. 4) (Hosler et al. 1989). REX-1 is highly expressed in embryonal carcinoma cells and is repressed during differentiation. The REX-1 protein contains four zinc finger motifs and a highly acidic domain, suggesting a possible function as a transcription factor.

The $4 \mathrm{Al}$ and $R E X-1$ sequences diverged at the boundary between the third exon and adjacent intron ( $\mathrm{L}$. Gudas, pers. comm.). The 4Al flanking sequence detected a single 1.8-kb RNA expressed in D3 cells, (the $R E X-1$ transcript) and an additional $2.1-\mathrm{kb}$ transcript in 4Al cells (Fig. 3A). The larger transcript also hybridized to his and corresponded to a fusion transcript in which 275 nucleotides of cellular RNA was appended to U3His, as predicted from the structure of the U3His-REX-1 fusion gene (Fig. 3B). These results support the notion that 
A

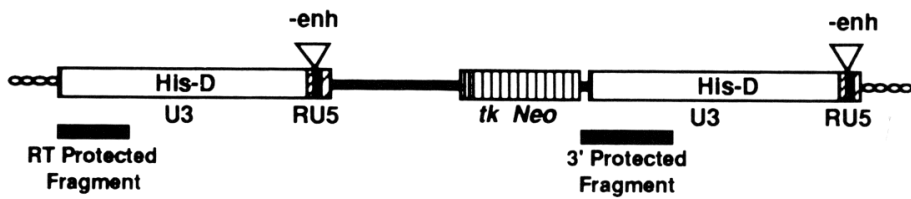

B

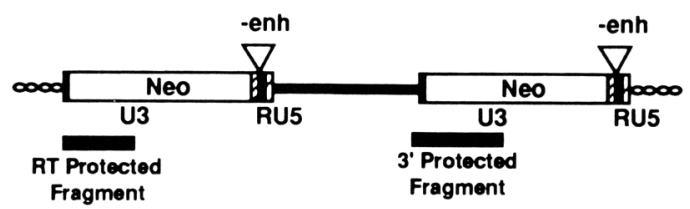

C
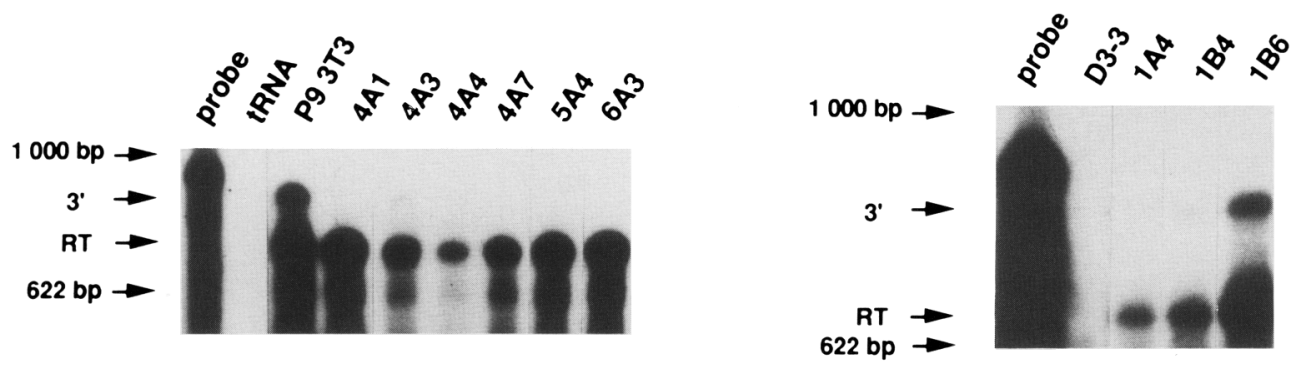

Figure 2. Ribonuclease protection analysis of provirus transcripts. Structure of U3His $\{A \mid$ and U3Neo $(B)$ proviruses. (His-D) histidinol-dehydrogenase-coding sequences; (- enh) deletion in U3 removing the viral enhancer; (tk) HSV-2 thymidine kinase promoter; (Neo) neomycin phosphotransferase-coding sequences; (U3RU5) regions of the viral LTR. Fragments protected at the $5^{\prime}$ [RT (readthrough transcripts), ] and $3^{\prime}$ ends of the provirus are indicated below each provirus. Lanes in $C$ are designated as follows: (Probe) Native probe; (tRNA) tRNA control; (P93T3) His ${ }^{\mathrm{r}}$ NIH-3T3 clone; (4Al-6A3) His ${ }^{\mathrm{r}}$ ES cell clones. Lanes in $D$ are designated as follows: (Probe) Native probe; (D3-3) His $^{\mathrm{r}}$ ES cell clone; (1A4, 1B4, 1B6) Neo $^{\mathrm{r}}$ ES cell clones. Size markers at left were estimated from the relative mobilities of radiolabeled 1-kb ladder (BRL) and pBR322 MspI restriction fragments.

U3 gene expression is activated by integrations within or near untranslated 5' exons.

The body of the $4 \mathrm{Al}$ provirus was deleted by homologous recombination between the LTRs (Fig. 4). Sequences downstream of the provirus appeared conserved because hybridization to $R E X-1$ cDNA probes failed to detect gross sequence rearrangements or deletions downstream of the provirus integration site. Furthermore, the size of the restriction fragment occupied by the provirus was exactly the size expected for a single U3His LTR (data not shown).

\section{Germ-line transmission of genes disrupted by $\mathrm{U} 3 \mathrm{His}$ or $\mathrm{U} 3 \mathrm{NeO}$ proviruses}

C57BL6 blastocysts were injected with $\mathrm{His}^{\mathrm{r}}$ and $\mathrm{Neo}^{\mathrm{r}} \mathrm{ES}$ cells and transferred to pseudopregnant CDl foster mothers (Hogan et al. 1986). When the resulting male chimeras were mated, a high incidence of germ-line transmission (five of seven $\mathrm{His}^{\mathrm{r}}$ and three of three $\mathrm{Neo}^{\mathrm{r}}$ lines tested) was observed (Table 1), indicating that infection and selection in histidinol or G418 did not affect stem cell totipotency. However, except for $4 \mathrm{Al}$ and 4A4, chimeras derived from His $^{\mathrm{r}}$ lines produced only a few Agouti offspring, and only one U3His fusion gene was passed into the germ line. In contrast, all U3Neo fusion genes were transmitted to transgenic offspring (Table 1).

Of the four disrupted genes introduced into the germ line, three were autosomal and two (4A4 and 1B6) resulted in embryonic lethalities when bred to homozygosity (Table 2). The embryos appeared to die after implantation because approximately one-fourth of the fetuses were in the process of being reabsorbed by day 8-9 postcoitum. One cell line (1B4) generated offspring homozygous for the disrupted allele; however, no obvious abnormality was observed. The fourth disrupted gene (1A4) was X-linked. However, both males and females homozygous for the disrupted gene were apparently normal (Table 2).

Coincidentally, the 4A4 and 1B6 inserts that generated lethal phenotypes did not hybridize to cellular transcripts (Table 1), whereas cellular transcripts were detected with sequences flanking the 1A4 and 1B4 inserts (Fig. 3). Thus, the mutagenic potential of the viruses seems extremely high, as judged by both molecular and phenotypic criteria. 
Table 1. Summary of results obtained with ES cell lines and cloned flanking sequences

\begin{tabular}{|c|c|c|c|c|c|}
\hline $\begin{array}{l}\text { ES cell } \\
\text { line }\end{array}$ & $\begin{array}{l}\text { U3 } \\
\text { gene }\end{array}$ & $\begin{array}{l}\text { Provirus flanking } \\
\text { DNA (nucleotides) }\end{array}$ & $\begin{array}{l}\text { Hybridization } \\
\text { to cellular } \\
\text { transcripts }\end{array}$ & $\begin{array}{l}\text { Germ-line } \\
\text { transmission }\end{array}$ & $\begin{array}{l}\text { Fusion-gene } \\
\text { inheritance }\end{array}$ \\
\hline $4 \mathrm{Al}$ & his & $315(\mathrm{M})$ & + & + & $-(0 / 20)$ \\
\hline $4 \mathrm{~A} 3^{\mathrm{b}}$ & his & $615(\mathrm{M})$ & + & + & $-\langle 0 / 1\rangle$ \\
\hline $4 \mathrm{~A} 4$ & his & $300(\mathrm{H})$ & - & + & $+(3 / 7)$ \\
\hline $4 \mathrm{~A} 7$ & his & $185(\mathrm{M})$ & + & + & $-\{0 / 2\}$ \\
\hline $5 \mathrm{~A} 4$ & his & $90(\mathrm{H})$ & - & + & $-(0 / 6)$ \\
\hline $6 \mathrm{~A} 3$ & his & $410(\mathrm{H})$ & - & - & - \\
\hline $1 \mathrm{~A} 4$ & neo & $38(\mathrm{H})$ & + & + & $+(11 / 26)$ \\
\hline 1B4 & neo & $275(\mathrm{H})$ & + & + & $+\{16 / 26\}$ \\
\hline $1 \mathrm{~B} 6$ & neo & $245(\mathrm{M})$ & - & $t$ & $+(6 / 10)$ \\
\hline
\end{tabular}

Genomic DNAs from $\mathrm{His}^{\mathrm{r}} \mathrm{Neo}^{\mathrm{r}}$ cell lines were digested with $\mathrm{MseI}$ (M) or HinfI (H) and ligated at concentrations of $5 \mu \mathrm{g} / \mathrm{ml}$ to obtain circular molecules. After cleavage with PvuII, $1 \mu \mathrm{g}$ of DNA from each sample was used for PCR as described in Materials and methods. Numbers in the last column indicate the frequency of fusion gene inheritance and the number of Agouti offspring tested.

${ }^{a}$ Southern blot analysis revealed that all flanking sequences hybridized to a single restriction fragment in ES cell DNA

${ }^{\mathrm{b}} \mathrm{A}$ sibling of clone $4 \mathrm{~A} 3$ was isolated from the same culture dish and failed to contribute to the germ line.

Finally none of 20 Agouti offspring analyzed inherited the U3His-REX-1 fusion gene (Table 1). The reasons for this are not known but several possibilities merit consideration. First, the $4 \mathrm{Al}$ cell line may have been contaminated by other ES cells which contributed to the germline. However, this seems unlikely, because each of the 10 subclones analyzed carried the U3His-REX-1 fusion gene. Second, since $R E X-1$ is actively transcribed in developing spermatocyte (Rogers et al. 1991), loss of $R E X-1$ functions may adversely affect post-meiotic sperm. Alternatively, as with herpes simplex virus (HSV) thymidine kinase (Wilkie et al. 1991), expression of his-

A

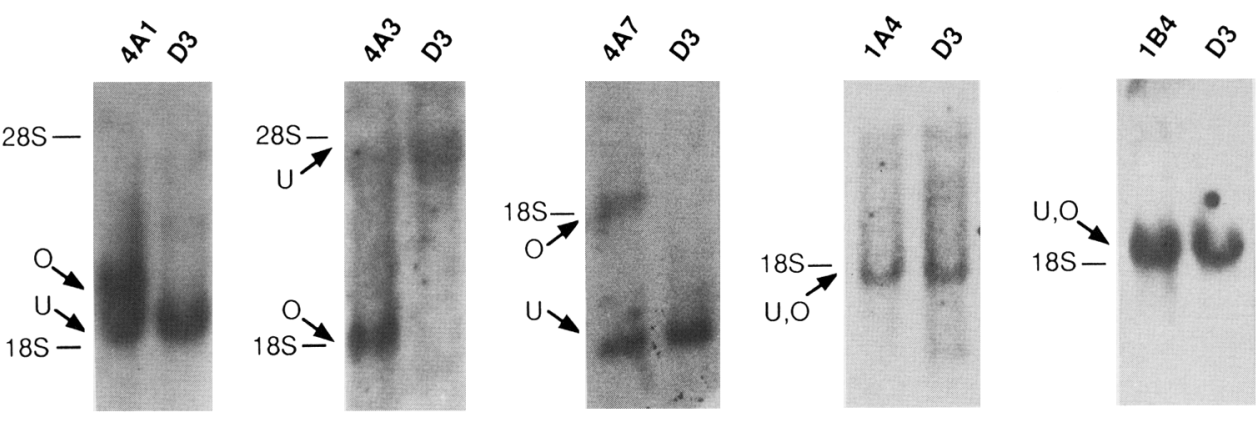

B
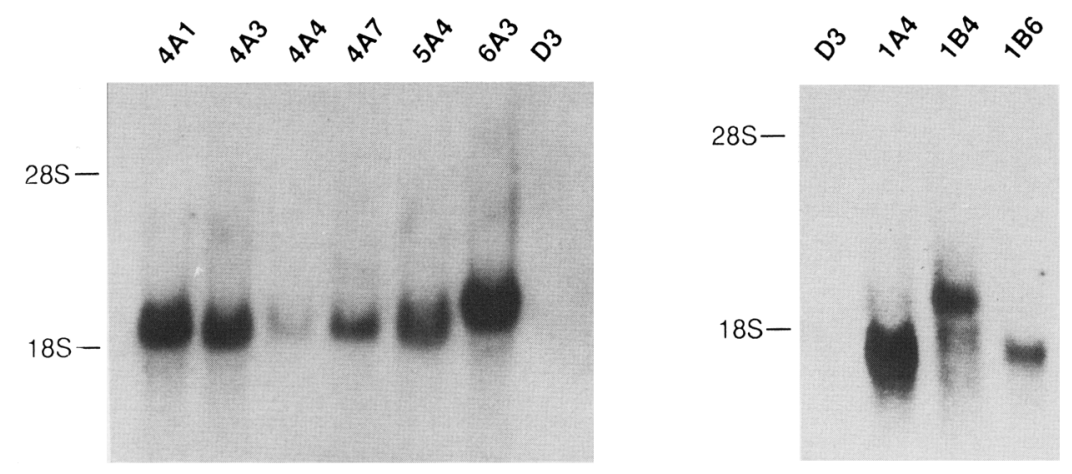

Figure 3. Northern blot analysis of cellular transcripts and cell-virus fusion genes. RNAs $(20 \mu g)$ from uninfected and virus-infected D3 cell lines were hybridized to ${ }^{32}$ P-labeled probes derived from flanking cellular sequences $(A)$ and his or neo sequences $(B)$. Transcripts from unoccupied $(\mathrm{U})$ and occupied $(\mathrm{O})$ alleles are indicated by arrows. In each case, fusion transcripts $(O)$ comigrated with transcripts in $B$ that hybridized to the appropriate his or neo probe. Fusion transcripts $1 \mathrm{~A} 4$ and $1 \mathrm{~B} 4(\mathrm{O})$ were similar in size to the cellular transcript $(\mathrm{U})$. Mobilities of RNAs are indicated. 


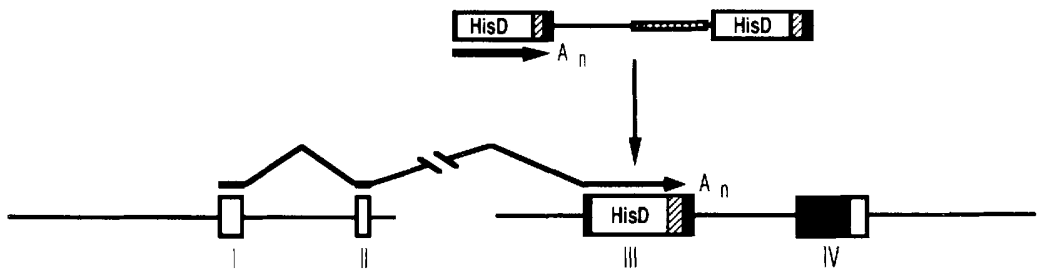

Figure 4. Disruption of $R E X-1$ by U3His. (A) Structure of $R E X-1$ gene in $4 \mathrm{Al}$ cells after integration of U3His and homologous recombination between the LTRs; the four $R E X-1$ exons are indicated with protein-coding sequences shown in black (Betsy Hosler and Lorraine Gudas, pers. comm.) (B) Sequence comparison between the 4Al flanking sequence (top) and $R E X-1$ cDNA (bottom).
B

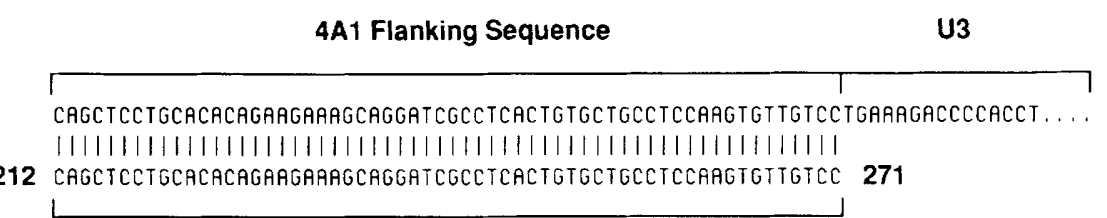

REX 1 CDNA Sequence tidinol-dehydrogenase in may affect sperm fertility. Finally, transmission of the fusion gene may have been prevented by other chromsomal abnormalities linked to the provirus.

\section{Discussion}

Two retrovirus promoter trap vectors have been used to induce mutations in totipotent ES cells. Retrovirus vectors containing hisD or neo sequences inserted into the U3 region exhibited a normal ability to be passaged to D3-ES cells, generating proviruses flanked by the U3 genes. Selection for his or neo expression produced cell clones in which the U3 genes in the 5'LTR were expressed on transcripts initiating in the flanking cellular DNA. Most cell lines generated germ-line chimeras, indicating that selection in histidinol or G418 does not adversely affect ES cell totipotency. However, fusion genes obtained following G418 selection were passed to the germ line much more efficiently than U3His fusion genes. Histidinol may induce differentiation of ES cells, as has been observed with other cell types (Pilz et al. 1987; Nordenberg et al. 1989). Nevertheless, his provides an alternative selectable marker in ES cells.

Sequences adjacent to U3His and U3Neo proviruses hybridized to single-copy DNA and frequently contained transcribed exons. One activating integration occurred in the third untranslated exon of the $R E X-1$ gene. These observations are consistent with the notion that promoter trap vectors select for integrations into $5^{\prime}$ regions of genes transcribed by RNA polymerase II. The fact that promoters transcribed by RNA polymerases I and III do not activate U3 gene expression was not unexpected because the resulting fusion transcripts lack $5^{\prime}$ caps and are not processed or translated efficiently (Banerjee 1980; Sisodia et al. 1987). In addition, polymerase III transcripts may terminate in short thymidine stretches present in the U3 genes (Bogenhagen et al. 1981).

Promoter trap mutagenesis provides a general method to study gene functions in mice. Several features of the approach are particularly powerful. First, retrovirus integration, unlike transferred DNA, preserves both viral

Table 2. Inheritance of U3His and U3Neo fusion genes

\begin{tabular}{|c|c|c|c|c|c|}
\hline \multirow[b]{2}{*}{ Clone } & \multirow[b]{2}{*}{ Number } & \multicolumn{3}{|c|}{ Inheritance pattern } & \multirow[b]{2}{*}{ Phenotype } \\
\hline & & heterozygotes & $\begin{array}{l}\text { homozygotes } \\
\text { (wild type) }\end{array}$ & $\begin{array}{l}\text { homozygotes } \\
\text { (fusion gene) }\end{array}$ & \\
\hline $4 \mathrm{~A} 4$ & 21 & 17 & 4 & 0 & $\begin{array}{c}\text { embryonic death } \\
\{9 / 32\}\end{array}$ \\
\hline $1 A 4^{a}$ & $\begin{array}{c}\text { male }(12) \\
\text { female (11) }\end{array}$ & $\begin{array}{c}\text { male }\{0\} \\
\text { female }\{3 \mid\end{array}$ & $\begin{array}{c}\text { male }(6) \\
\text { female }(0)\end{array}$ & $\begin{array}{c}\text { male }(6) \\
\text { female }(8)\end{array}$ & $\begin{array}{l}\text { male }(\text { N.O. })^{a} \\
\left.\text { female }^{\text {(N.O. }}\right)^{a}\end{array}$ \\
\hline 1B4 & 10 & 2 & 6 & 2 & N.O. ${ }^{a}$ \\
\hline $1 \mathrm{~B} 6$ & 52 & 20 & 32 & 0 & $\begin{array}{c}\text { embryonic death } \\
\{11 / 45\}\end{array}$ \\
\hline
\end{tabular}

Heterozygous mice derived from the indicated cell lines were mated, and DNA from the offspring was analyzed by Southern blot hybridization. Restriction fragments corresponding to the normal and disrupted alleles were distinguished by hybridization flanking sequence probes. Numbers in parantheses indicate the number of embryos in the process of being reabsorbed per total number of embryos after 8-10 days postcoitum.

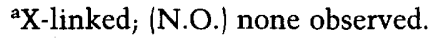


and cellular sequences so that the structure of the recombination product is predictable. Second, promoter trap selection favors integrations in or near $5^{\prime}$ exons; consequently, $60 \%$ of upstream-flanking probes hybridized to transcripts expressed by both the occupied and unoccupied alleles. Thus, as with vectors activated by gene splicing (Brenner et al. 1989; Gossler et al. 1989; Friedrich and Soriano 1991), promoter trap viruses greatly simplify isolating cDNAs of the disrupted genes, as compared with vectors in which expression of a marker gene is activated by transcriptional enhancers (Hamada 1986; Taketo and Tanaka 1987; Gossler et al. 1989). Finally, selection for cells containing fusion genes significantly reduces the number of recombinants needed to screen for loss of gene function, as compared with cells in which viruses have integrated randomly. Two of four disrupted genes that have been passed to the germ line resulted in embryonic death when bred to homozygosity. In short, the mutagenic potential of promoter trap vectors seems extremely high, as judged either by molecular or biological criteria. The frequency of recessive mutations was similar to a recent study by Friedrich and Soriano in which 9 of 24 activating integrations caused recessive lethal mutations (Friedrich and Soriano 1991). Further analysis will be required to establish whether disrupted genes identified by molecular means generate subtle phenotypes as is frequently observed after specific genes have been targeted (Zijlstra et al. 1989; Zijlstra et al. 1990; Schorie et al. 1991; Soriano et al. 1991).

Two considerations suggest that most expressed genes can be targeted by promoter trap selection. First, the number of sites in the genome that can activate U3 gene expression, as judged either by the fraction of proviruses that express U3 genes (von Melchner and Ruley 1989; Reddy et al. 1991) or by the frequency with which haploid genes can be targeted following promoter trap selection (W. Chang, S.C. Hubbard, C. Friedel, and H.E. Ruley, in prep.), is similar to the total number of expressed genes $\left(2 \times 10^{4}\right.$ to $\left.4 \times 10^{4}\right)$, as judged by RNA renaturation kinetics (Lewin 1975). Second, genes displaced from their promoters as a result of virus integration are functionally inactivated (W. Chang, S.C. Hubbard, C. Friedel, and H.E. Ruley, in prep.). However, some genes may be easier to disrupt than others because integration may be biased for certain regions (Rohdewohld et al. 1987; Shih et al. 1988; Peckham et al. 1989; Scherdin et al. 1990), and regulated genes generally have longer untranslated leaders than widely expressed, housekeeping genes (Kozak 1987a).

These features of promoter trap mutagenesis make it feasible to screen a large collection of recombinant clones for disruptions of interesting genes before constructing strains of mice that harbor particular mutant alleles. For example, 5'-flanking regions can be isolated rapidly by inverse PCR and analyzed to determine whether the disrupted genes (1) have been cloned previously (e.g., $R E X-1),(2)$ map near important loci or chromosomal regions, and $(3)$ are expressed in a tissue-specific manner. Although promoter trap mutagenesis is presently limited to genes expressed at the time of virus integration, other vectors (e.g., U3lacZ) and improved methods to induce ES cell differentiation in vitro will simplify recovering mutations in developmentally regulated genes.

As physical maps of the mouse genome become more detailed and additional genes are characterized, collections of characterized ES cell clones will provide an increasingly important resource. For example, representation of a newly discovered gene in a library of ES cell integrants could eliminate the necessity of targeting the gene separately by homologous recombination. Finally, the efficiency with which disrupted loci can be introduced into the germ line makes it feasible to identify biologically significant genes directly, by assessing the phenotypes of mice homozygous for the disrupted alleles.

\section{Materials and methods}

Plasmids

pGgU3Neoen $\mid$ - | was derived from pGgU3TkNeoU3Hisen $\mid$ - | (von Melchner and Ruley 1989) by replacing the hisD gene with a 900-nucleotides fragment containing the neo-coding sequence. The neo sequences were amplified by PCR from pGgU3TkNeoU3Hisen $(-1$.

Viruses and cell cultures

ES-D3 cells $\left(1 \times 10^{6}\right)$ were infected with the U3His virus at a m.o.i. of $1 \mathrm{Neo}^{\mathrm{r}} \mathrm{CFU} / \mathrm{cell}$ (as assayed on NIH-3T3 cells), as described previously (von Melchner and Ruley 1989). ES cell clones surviving selection in $3.5 \mathrm{~mm}$ histidinol were isolated after 14-15 days and expanded on irradiated $(3.2 \mathrm{~Gy})$ mouse embryo fibroblast (MEF) feeder layers (prepared from 16-day-old embryos) in the absence of L-histidinol. The growth medium for ES cells was Dulbecco's modified Eagle medium (DMEM) (GIBCO) supplemented with $15 \%$ preselected and heat-inactivated fetal calf serum, $100 \mathrm{~mm}$ nonessential amino acids (GIBCO), $0.1 \mathrm{~mm} \beta$-mercaptoethanol (Bio-Rad), $5 \mathrm{mg} / \mathrm{ml}$ of penicillin and streptomycin, and $10^{3} \mathrm{U} / \mathrm{ml}$ of leukemia inhibitory factor (LIF) (Esgro ${ }^{\mathrm{R}}$; Amrad, Australia).

\section{Amplification and cloning of upstream sequences}

Genomic DNAs from $\mathrm{His}^{\mathrm{r}}$ and $\mathrm{Neo}^{\mathrm{x}}$ cell lines were digested with $M s e I(M)$ or $\operatorname{Hinfl}(\mathrm{H})$ and ligated at concentrations of $5 \mu \mathrm{g} /$ $\mathrm{ml}$ to obtain circular molecules. After cleavage with PvuII, $1 \mu \mathrm{g}$ of DNA from each sample was used for PCR as described previously (von Melchner et al. 1990). Oligonucleotide primers complementary to his (5'-CCAGTCAATCAGGGTATTGA-3' and 5'-GTAAGCTTTAAAACAGAAGTGACAGCGCTACGCG-3' for Msel circles; 5'-CCAGTCAATCAGGGTATTGA-3' and $5^{\prime}$-GTAAGCTTTGCAGGAAATCTTAACGTCGGCGG$3^{\prime}$ for HinfI circles) or neo (5'-CCATCTTGTTCAATCATGCGAAACGATCC-3' and 5'-GTAAGCTTGCTCCCGATTCGCAGCGCATCGCCTT-3' for MseI circles; 5'-CCATCTTGT-

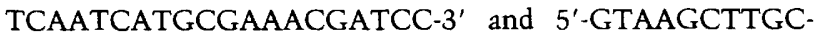
GATGCCTGCTTGCCGAATATCATG- $3^{\prime}$ for HinfI circles) sequences were used. Gel-purified PCR products were cleaved with NheI and HindIII and ligated to Bluescript(KS -) (Stratagenel plasmids digested with $\mathrm{XbaI}$ and HindIII. A 38-nucleotide synthetic oligonucleotide complementary to the 1A4 flanking 
sequence was labeled by terminal transferase as described previously (Johnson 1991).

\section{Nucleic acid hybridization analyses and ribonuclease protection assays}

Nucleic acid hybridizations with labeled flanking sequences and ${ }^{32} \mathrm{P}$-labeled probes complementary to the U3His proviruscoding strand were prepared as described previously (Reddy et al. 1991). Probes complementary to the U3Neo provirus-coding strand were prepared by using T3 RNA polymerase to transcribe an 820-nucleotide BamHI-NaeI fragment of pGgU3Neoen $(-)$ cloned into Bluescript(KS -). Hybridization of RNA samples to antisense RNA probes and RNase digests were performed as described previously (von Melchner and Ruley 1989). Protected fragments were resolved on denaturing $6 \%$ polyacrylamide $/ 8.3$ $\mathrm{M}$ urea gels and visualized by autoradiography.

\section{Construction and analysis of germ-line chimeras}

Germ-line contribution of His $^{\mathrm{r}}$ ES-D3 (129; Agouti/Agouti) cell lines was tested by injecting each of 15-20 C57BL6 blastocysts (3.5 days) with 15-20 cells. The blastocysts were implanted into the uterus of pseudopregnant CD1 recipients as described previously (Hogan et al. 1986), and chimeric males were mated with C57BL6 mice. Inheritance of the D3 Agouti coat color marker was observed in $3-100 \%$ of the offspring from $50 \%$ of the male chimeras.

\section{Acknowledgments}

We thank Dr. Lorraine Gudas for providing unpublished genomic sequence data on REX-1; Marge Cumminskey and John Mkandawire for technical assistance, and Drs. Janet Rossant and Rudolph Jaenisch for subclones of D3 cells provided by Dr. Rolf Kemler. This work was supported by National Institutes of Health grants R01CA40402, PO1CA42063, and PO1 HL41484 to H.E.R. and partially supported by a Cancer Center Core grant (P30CA14051) to P.A. Sharp.

The publication costs of this article were defrayed in part by payment of page charges. This article must therefore be hereby marked "advertisement" in accordance with 18 USC section 1734 solely to indicate this fact.

\section{References}

Akgün, E., M. Ziegler, and M. Grez. 1991. Determinant of retrovirus gene expression in embryonal carcinoma cells. $J$. Virol. 65: 382-388.

Banerjee, A.S. 1980. 5'-Terminal cap structure in eucaryotic messenger ribonucleic acids. Microbiol. Rev. 44: 175-205.

Barklis, E., R.C. Mulligan, and R. Jaenisch. 1986. Chromosomal position or virus mutation permits retrovirus expression in embryonal carcinoma cells. Cell 47: 391-399.

Bogenhagen, D.F., S. Sakonju, and D.D. Brown. 1981. Nucleotide sequences in Xenopus 5S DNA required for transcription termination. Cell 24: 261-270.

Brenner, D.G., S. Lin-Chao, and S.N. Cohen. 1989. Analysis of mammalian cell genetic regulation in situ by using retrovirus-derived "portable exons" carrying the Escherichia coli lacZ gene. Proc. Natl. Acad. Sci. 86: 5517-5521.

Capecchi, M.R. 1989. Altering the genome by homologous recombination. Science 244: 1288-1292.

Doetschman, T.C., H. Eistetter, M. Katz, W. Schmidt, and R. Kemler. 1985. The in vitro development of blastocyst-de- rived embryonic stem cell lines: Formation of visceral yolk sac, blood islands, and myocardium. J. Embryol. Exp. Morphol. 87: $27-45$.

Evans, M.J. and M.H. Kaufman. 1981. Establishment in culture of pluripotential cells from mouse embryos. Nature 292: $154-156$.

Evans, M.J., A. Bradley, M.R. Kuehn, and E.J. Robertson. 1985. The ability of EK cells to form chimeras after selection of clones in G418 and some observations on the integration of retroviral vector proviral DNA into EK cells. Cold Spring Harbor Symp. Quant. Biol. 50: 685-689.

Feuer, G., M. Taketo, R.C. Hanecak, and H. Fan. 1989. Two blocks in Moloney murine leukemia virus expression in undifferentiated F9 embryonal carcinoma cells as determined by transient expression assays. J. Virol. 63: 2317-2324.

Friedrich, G. and P. Soriano. 1991. Promoter traps in embryonic stem cells: A genetic screen to identify and mutate developmental genes in mice. Genes \& Dev. 5: 1513-1523.

Gautsch, J.W. and M.C. Wilson. 1983. Delayed de novo methylation in teratocarcinoma suggests additional tissue-specific mechanisms for controlling gene expression. Nature 301: 32-37.

Gossler, A., A.L. Joyner, J. Rossant, and W.C. Skarnes. 1989. Mouse embryonic stem cells and reporter constructs to detect developmentally regulated genes. Science 244: 463-465.

Gridley, T., O. Soriano, and R. Jaenisch. 1987. Insertional mutagenesis in mice. Trends Genet. 3: 162-166.

Hamada, H. 1986. Activation of an enhancerless gene by chromosomal integration. Mol. Cell. Biol. 6: 4179-4184.

Hogan, B., F. Constantini, and E. Lacy. 1986. Manipulating the mouse embryo. A laboratory manual. Cold Spring Harbor Laboratory, Cold Spring Harbor, New York.

Hosler, B.A., G.J. LaRosa, J.F. Grippo, and L. Gudas. 1989. Expression of $R E X-1$, a gene containing zinc finger motifs, is rapidly reduced by retinoic acid in F9 teratocarcinoma cells. Mol. Cell. Biol. 9: 5623-5629.

Jaenisch, R. 1988. Transgenic animals. Science 240: 1468-1474. Jahner, D., H. Stuhlmann, C.L. Stewart, K. Harbers, J. Lohler, I. Simon, and R. Jaenisch. 1982. De novo methylation and expression of retroviral genomes during mouse embryogenesis. Nature 298: 623-628.

Johnson, K.R. 1991. Improved oligonucleotide labeling. Hybridization assay for endogenous murine leukemia proviruses. Mammal. Genome 1: 260-262.

Kaufman, R.J., P. Murtha, and M.V. Davies. 1987. Translational efficiency of polycistronic mRNAs and their utilization to express heterologous genes in mammalian cells. EMBO $\%$ 6: 187-193.

Kessel, M. and P. Gruss. 1990. Murine developmental control genes. Science 249: 374-379.

King, W., M. Patel, L. Lober, S. Goff, and M. Nguyen-Huu. 1985. Insertion mutagenesis of embryonal carcinoma cells by retroviruses. Science 228: 554-558.

Kozak, M. 1980. Evaluation of the "scanning model" for initiation of protein synthesis in eucaryotes. Cell 22: 7-8.

- 1987a. An analysis of $5^{\prime}$-noncoding sequences from 699 vertebrate messenger RNAs. Nucleic Acids Res. 15: 81258148 .

- 1987b. Effects of intercistronic length on the efficiency of reinitiation by eucaryotic ribosomes. Mol. Cell. Biol. 7: 3438-3445.

Kratochwil, K.K., K. von der Mark, E. Kollar, R. Jaenisch, K. Mooslehner, M. Schwarz, K. Haase, I. Gmachl, and K. Harbers. 1989. Retrovirus-induced insertional mutation in Mov13 mice affects collagen expression in tissue-specific manner. Cell 57: 807-816. 
Lewin, B. 1975. Units of transcription and translation: Sequence components of heterogeneous nuclear RNA and messenger RNA. Cell 4: 77-93.

Loh, T.P., L.L. Sievert, and R.W. Scott. 1990. Evidence for a stem-cell specific repressor of Moloney murine leukemia virus expression in embryonal carcinoma cells. Mol. Cell. Biol. 10: $4045-4057$.

Martin, G. 1981. Isolation of a pluripotent cell line from early mouse embryos cultured in medium conditioned by teratocarcinoma stem cells. Proc. Natl. Acad. Sci. 78: 7634-7638.

Mulligan, R.C. and P. Berg. 1981. Selection for animal cells that express the Escherichia coli gene coding for xanthine-guanine phosphoribosyl transferase. Proc. Natl. Acad. Sci. 78: 2072-2076.

Niwa, O., Y. Yokota, H. Ishida, and T. Sugahara. 1983. Independent mechanisms involved in suppression of the Moloney leukemia virus genome during differentiation of murine teratocarcinoma cells. Cell 32: 1105-1113.

Nordenberg, J., L. Wasserman, H. Gutman, E. Beery, and A. Novogrodsky. 1989. Growth inhibition and induction of phenotypic alterations by L-histidinol in B16 melanoma cells. Cancer Lett. 47: 193-197.

Peabody, D.S., S. Subramani, and P. Berg. 1986. Effect of Upstream reading frames on translation efficiency in simian virus 40 recombinants. Mol. Cell. Biol. 6: 2704-2711.

Peckham, I., S. Sobel, J. Comer, R. Jaenisch, and E. Barklis. 1989. Retrovirus activation in embryonal carcinoma cells by cellular promoters. Genes \& Dev. 3: 2062-2071.

Pellicer, A., E.F. Wagner, A. El Kareh, M.J. Dewey, A.J. Reuser, S. Silverstein, R. Axel, and B. Mintz. 1980. Introduction of a viral thymidine kinase gene and the human $\beta$-globin gene into developmentally multipotential mouse teratocarcinoma cells. Proc. Natl. Acad. Sci. 77: 2098-2102.

Petersen, R., G. Kempler, and E. Barklis. 1991. A stem cellspecific silencer in the primer-binding site of a retrovirus. Mol. Cell. Biol. 11: 1214-1221.

Pilz, R.B., G. Van den Berghe, and G.R. Boss. 1987. Induction of HL-60 differentiation by starvation for a single essential amino acid but not by protein synthesis inhibitors. J. Clin. Invest. 79: 1006-1009.

Reddy, S., J.V. DeGregori, H. von Melchner, and H.E. Ruley. 1991. Retrovirus promoter-trap vector to induce lacZ gene fusions in mammalian cells. I. Virol. 65: 1507-1515.

Reith, A.D. and A. Bernstein. 1991. Molecular basis of mouse developmental mutants. Genes \& Dev. 5: 1115-1123.

Robertson, E.J. 1987. Teratocarcinomas and embryonic stem cells. IRL Press, Oxford, Washington, D.C.

Robertson, E., A. Bradley, M. Kuehn, and M. Evans. 1986. Germline transmission of genes introduced into cultured pluripotential cells by retroviral vector. Nature 323: 445-448.

Rogers, M.B., B.A. Hosler, and L.J. Gudas. 1991. Specific expression of a retinoic acid-regulated, zinc-finger gene, $R E X-1$, in preimplanation embryos, trophoblast and spermatocytes. Development 113: 815-824.

Rohdewohld, H., H. Weiher, W. Reik, R. Jaenisch, and M. Breindl. 1987. Retrovirus integration and chromatin structure: Moloney murine leukemia proviral integration sites map near DNase I-hypersensitive sites. J. Virol. 61: 336-343.

Sanes, J.R., J.L.R. Rubenstein, and J.-F. Nicolas. 1986. Use of a recombinant retrovirus to study post-implantation cell lineage in mouse embryos. EMBO J. 5: 3133-3142.

Scherdin, U., K. Rhodes, and M. Breindl. 1990. Transcriptionally active genome regions are preferred targets for retrovirus integration. I. Virol. 64: 907-912.

Schnieke, A., K. Harbers, and R. Jaenisch. 1983. Embryonic lethal mutation in mice induced by retrovirus insertion into the $\alpha$ l(I) collagen gene. Nature 304: 315-320.

Schorie, H., T. Holtschke, T. Hünig, A. Schimpl, and I. Horak. 1991. Development and function of $T$ cells in mice rendered interleukin-2 deficient by gene targeting. Nature 352: 621624.

Shih, C.C., J.P. Stoye, and J.M. Coffin. 1988. Highly preferred targets for retrovinus integration. Cell 53: 531-537.

Sisodia, S.S., B. Sollner-Webb, and D.W. Cleveland. 1987. Specificity of RNA maturation pathways: RNAs transcribed by RNA polymerase III are not substrates for splicing or polyadenylation. Mol. Cell. Biol. 7: 3602-3612.

Sorge, J., A.E. Cutting, V.D. Erdman, and J.W. Gautsch. 1984. Integration-specific retrovirus expression in embryonal carcinoma cells. Proc. Natl. Acad. Sci, 81: 6627-6631.

Soriano, P., T. Gridley, and R. Jaenisch. 1987. Retroviruses and insertional mutagenesis in mice: Proviral integration at the Mov 34 locus leads to early embryonic death. Genes \& Dev. 1: 366-375.

Soriano, P., C. Montgomery, R. Geske, and A. Bradley. 1991. Targeted disruption of the c-src proto-oncogene leads to osteopetrosis in mice. Cell 64: 693-702.

Spence, S.E., D.J. Gilbert, D.A. Swing, N.G. Copeland, and N.A. Jenkins. 1989. Spontaneous germ line virus infection and retroviral insertional mutagenesis in eighteen transgenic Srev lines of mice. Mol. Cell. Biol. 9: 177-184.

Stewart, C.L., H. Stuhlmann, D. Jahner, and R. Jaenisch. 1982 De novo methylation, expression, and infectivity of retroviral genomes introduced into embryonal carcinoma cells. Proc. Natl. Acad. Sci. 79: 4098-4102.

Stewart, C.L., M. Vanek, and E.F. Wagner. 1985. Expression of foreign genes from retroviral vectors in mouse teratocarcinoma chimaeras. EMBO 1. 4: 3701-3709.

Taketo, M. and M. Tanaka. 1987. A cellular enhancer of retrovirus gene expression in embryonal carcinoma cells. Proc. Natl. Acad. Sci. 84: 3748-3752.

Tsukiyama, T., O. Niwa, and K. Yokoro. 1989. Mechanism of suppression of the long terminal repeat of Moloney leukemia virus in mouse embryonal carcinoma cells. Mol. Cell. Biol. 9: 4670-4676.

van der Putten, H., F.M. Botteri, A.D. Miller, M.G. Rosenfeld, H. Fan, R. M. Evans, and I.M. Verma. 1985. Efficient insertion of genes into the mouse germ line via retroviral vectors. Proc. Natl. Acad. Sci. 82: 6148-6152.

von Melchner, H. and H.E. Ruley. 1989. Identification of cellular promoters by using a retrovirus promoter trap. I. Virol. 63: $3227-3233$.

von Melchner, H., S. Reddy, and H.E. Ruley. 1990. Isolation of cellular promoters by using a retrovirus promoter trap. Proc. Natl. Acad. Sci. 87: 3733-3737.

Weiher, H., T. Noda, D.A. Gray, A.H. Sharpe, and R. Jaenisch. 1990. Transgenic mouse model of kidney disease: Insertional inactivation of ubiquitously expressed gene leads to nephrotic syndrome. Cell 62: 425-434.

Wilkie, T.M., R.R. Braun, W.J. Ehrman, R.D. Palmiter, and R.E. Hammer. 1991. Germ-line intrachromosomal recombination restores fertility in transgenic MyK-103 male mice. Genes \& Dev. 5: 38-48.

Zijlstra, M., E. Li, F. Saijadi, S. Subramani, and R. Jaenisch. 1989. Germ-line transmission of a disrupted $\beta_{2}$-microglobulin gene produced by homologous recombination in embryonic stem cells. Nature 342: 435-438.

Zijlstra, M., M. Bix, N.E. Simister, J.M. Loring, D.H. Raulet, and R. Jaenisch. 1990. 32 -Microglobulin deficient mice lack $\mathrm{CD}^{-} 8^{+}$cytolytic T cells. Nature 344: 742-746. 


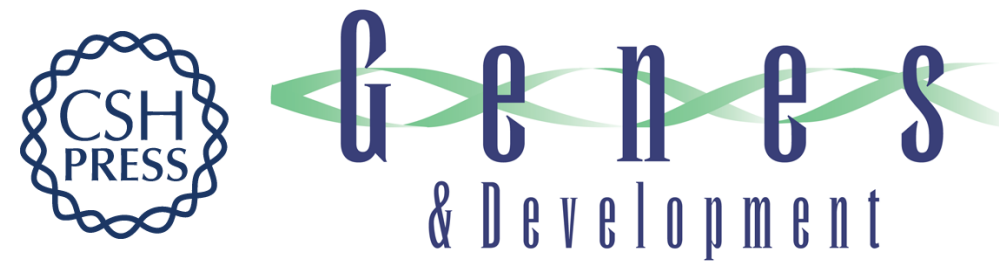

\section{Selective disruption of genes expressed in totipotent embryonal stem cells.}

$\mathrm{H}$ von Melchner, J V DeGregori, H Rayburn, et al.

Genes Dev. 1992, 6:

Access the most recent version at doi:10.1101/gad.6.6.919

References This article cites 63 articles, 37 of which can be accessed free at:

http://genesdev.cshlp.org/content/6/6/919.full.html\#ref-list-1

License

Email Alerting Receive free email alerts when new articles cite this article - sign up in the box at the top Service right corner of the article or click here.

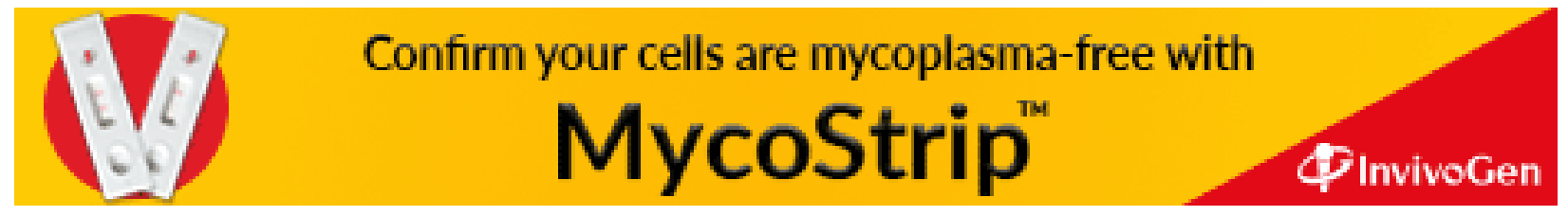

